\section{Only Kant Can Save Us}

\section{Nadia Urbinati}

\section{Heinrich Geiselberger (ed.)}

The Great Regression

London, Polity Press, 2017

Following in The Great Transformation's footsteps (Karl Polanyi, 1944), Heinrich Geiselberer has recently edited a collection of essays, The Great Regression. Published for the first time in German, it has been immediately translated into all the European languages. The title conveys the sense of distress which the project was born from. The design of the volume consists of asking to fifteen sociologists to express their thoughts on the condition of democracy after the Paris terrorist attacks which took place in 2015. Despite the similarities with the title of the work of Polanyi, this agile and easy reading book shows its own specific identity, at time emotional, between catastrophism and voluntarism. As we read in the introduction, the inspiring idea is the decline of the Western society, strongly "regressed, leaving behind a series of life standards hardly gained and believed consolidated by now". "Regress" pertains to the world we leave in, which is characterized by the values of cosmopolitanism and Enlightenment, the idea of the open mind and of the open borders. This noble culture has guided us as long as the world was divided into influence areas (the Cold War) and sovereignty had the power to make economic and social choices and to patrol the frontiers.
It looks like Kant's principles - our principles according to the authors of this volume- had moral power as long as they did not inspire politics, when the borders were there and it was possible to distinguish between "immigration" and "migration", Zygmunt Bauman writes; yet, not today, when the States cannot handle the "waves" of the hopeless people of the Earth. In the words of Umberto Eco (one of the ideal inspirers of the volume, together with Ralf Dahrendorf and Richard Rorty) the Third World "doesn't knock, it comes in, even if we disagree". According to Bruno Latour, the feeling which comes out is the following: "Masters in your own house! Back up!". The problem is that "there is no more "our own house", for no one. Out of here! We all need to move. Why? Well, because there is no planet able to realize the dreams of globalization".

The difficulty lies in the fact that we cannot be cosmopolitan by choice: we have to be so, that is it. And this is hard for those who are not pietistic like Kant was. When being tolerant becomes a job, the Enlightenment principles begin to falter. Rorty had already understood it: thirty years ago, he explained the difficulty of being tolerant when "those who are different" live close by, because it demands a hard work of self-control. Hence Rorty argued that we liberals look forward to going home at the end of the day to seek refuge in our private life, where we can say whatever we think and the art of "dealing" and "bargaining" is not that necessary. The world described in this volume is a place of fatigue, of effort. And the effort is, so it seems, proportional to the racial mixture and, above all, to the kind of racial proportion. Ivan Krastev uses Karen Stenner's category of "normative threat" to explain "the sensation that the integrity of the moral order is endangered and that the perceived "us" is disintegrating". The relation between the white "us" and the less- 


\section{BookReviews}

white world around us cannot be concealed

- it is in effect not simply the ethical mix the problem, but some kind of it. Again, Bauman writes: in 1990, New York City "counted in its population $43 \%$ of white people, $29 \%$ of black people, $21 \%$ of Hispanic people and $7 \%$ of Asian people. Twenty years later, in 2010, white people were only $33 \%$ of the population and close to become a minority". So, where does the problem of the fatigue of living immersed in diversity lie? It seems that it lies in the imbalanced relation between the whites and the others.

The situation is not better when we analyze our democratic societies. As Wolfgang Streeck writes, politics is not healthier than society, if it is true that the distance between "common people" and "well- educated people" is tearing apart democratic citizenship. Nevertheless, not all the chapters agree with these diagnoses and not all of them are equally convincing and acceptable. Donatella Della Porta reconstructs with care the attempts to fix democratic institutions pushed by the debt's crisis and by social rights' erosion. Starting from the participative budgets to the institutional imagination of Icelanders, who, with a synergy of procedures and methods (elections, referendum, draw and web consultation) have written a new constitution (which then the Parliament rejected, but which, in the European Commission's opinion, was properly written). In his ideal "letter to Juncker", David Van Reybrouck rightly observes that if democracy proves itself ineffective, it is, on the one hand, because of the European states' unwillingness to "want" a political Europe, and, on the other hand, because of the abuse of the referendum instrument by arrogant and unwise leaders.

But democracy 'regression' to where? Each essay of this book points the finger towards the decline of the European Union, populism, neoliberal hegemony, the erosion of the middle-class, the unleashing of the worst passions by old and new media and an "audience"-based politics. Arjun Appadurai has no doubt that we are going towards authoritarianism - whoever is the authoritarian leader: Putin, Erdogan or Trump. Nevertheless, are institutions and the procedures irrelevant? Turkey and the U.S. are not the same and it is wrong to conclude that those who voted for Trump voted "against democracy", because democracy does not work only when we like democracy's choices; until we can "vote" freely and can return to vote regularly, until we express opposition, there is democracy, regardless of the quality of decisions. The art of distinction should help us not to put on the same page democracy, populism and authoritarianism. Surely César Rendueles is right when he hopes for democracies to deal with citizens' ethic culture (actually, a problem as old as democracies themselves), but it is simplistic to think that the game's procedures and rules are just formal issues.

Furthermore, instead of thinking of the West as "one", what if we just look at the differences within the West? It is from here that Slavoj Žižek starts, in order to formulate the final question: "what to do?". An old Leninist, indifferent to catastrophism and fatalism, Žižek turns to the strategic reason and voluntarism. We should try to combine "the two levels: universality against the sense of patriotic belonging, and capitalism against the left-wing anti-capitalism", without going over the traveled roads (which have been already defeated or are undesirable). This means that "we must shift our attention from the big, bad, populist wolf to the real problem: the weakness of the "rational" moderate position". The "nonmoderate" position he proposes is the following: giving Kant's cosmopolitanism some legal and political roots. Basically, this means taking Trump seriously and bringing Trumpism 
to its radical consequences: the fact that nation-states no longer work as they used to, so that those who are against right-wing populism should have the courage to propose "a draft of new and different international agreements: agreements imposing Banks control, agreements on ecological standards, workers' rights, health care, protection of sexual and ethnic minorities, etc.". Žižek does not tell us which is the entity capable of doing so. But the book suggests us some direction, since it begins deliberately with a confession of pessimism and ends with an appeal to Kant - from the diagnosis of regression to the Enlightenment cure. 